\title{
FIRE HISTORY OF THE NORTHERN PART OF THE TASMANIAN WILDERNESS WORLD HERITAGE AREA AND ITS ASSOCIATED REGIONS
}

\author{
by K. A. Johnson and J. B. Marsden-Smedley \\ (with one table and two text-figures)
}

Johnson, K. A. \& MARSDEn-Smedley, J. B., 2002 (31:xii): Fire history of the northern part of the Tasmanian Wilderness World Heritage Area and its associated regions. Papers and Proceedings of the Royal Society of Tasmania 136: 145-152. https://doi.org/10.26749/rstpp.136.145 ISSN 0080-4703. Fire Management Section, Parks and Wildlife Service, GPO Box 44 Hobart, Tas 7001 , Australia.

Fire history (from the 1820s to 2000) in the northern quarter of the Tasmanian Wilderness World Heritage Area and its associated regions is discussed in this paper. This area includes Cradle Mountain-Lake St Clair National Park, Granite Tor Conservation Area, Walls of Jerusalem National Park and the Central Plateau Conservation Area west of Great Lake. In common with fire history in southwest Tasmania, there have been major changes in fire regimes during the last 180 years, with major fires in the 1890s (most probably in 189697 or 1897-98 or both) and the 1930s (most probably in 1933-34). However, in contrast to southwest Tasmania, there were major fires until the early 1960s: in the early 1950s in the Cradle Mountain-Lake St Clair National Park and Granite Tor Conservation Area, and in 1960-61 in the Walls of Jerusalem National Park and the Central Plateau Conservation Area. Between the 1930s and 1960s over 40\% of the study area or about 129000 ha was burnt. About half of the study area's fire-sensitive vegetation (i.e., alpine, subalpine heath, subalpine rainforest, rainforest and native conifer) was burnt in these fires. The last of these fires - the 1960-61 Central Plateau fire was the biggest and most destructive fire in the World Heritage Area since the 1930s. Less than 3\% of the study area was burnt between 1970 and 2000.

On Wednesday, November 16, had the camp moved to the foot of Barn Bluff; and on Sunday, the 20"h, taking three of the party with me, I went to the summit of that mountain, hoping to obtain a good view of the country to the westward. By aneroid I made the summit of Barn Bluff 5045 feet above sea, but failed to get a good view of the country I wanted to see, owing to the dense volume of smoke arising from numerous bush fires enveloping the country in almost every direction.

E. G. Innes, District Surveyor, 1896

Key words: fire history, western Tasmania, World Heritage Area.

\section{INTRODUCTION}

There is considerable anecdotal evidence of major changes in the fire regime of Tasmania's Wilderness World Heritage Area (WHA) since the removal of the indigenous Tasmanians in the early nineteenth century. The changes are reflected in the extensive areas of highly fire-sensitive alpine, rainforest and native conifer plant communities that have been severely degraded by fire in the past 180 years (Brown 1988, Peterson 1990, Robertson \& Duncan 1991, Corbett unpubl. 1995). These plant communities are very slow to recover after fire (in the order of 500 to 1000 years). They are also considered to be of world heritage significance (PWS 1999). Their destruction is therefore of great concern and the changes in fire regime have major implications for management and ecological processes of the WHA.

The fire history of southwest Tasmania over the past 180 years has been reported (Marsden-Smedley 1998a, b). That study area encompassed Southwest and Franklin-Gordon Wild Rivers National Parks and those parts of the Southwest Conservation Area that are on Cape Sorell or adjacent to the King River and Macquarie Harbour. This paper continues the study of fire history to include Cradle Mountain-Lake St Clair National Park, Walls of Jerusalem National Park, Granite Tor Conservation Area and the part of the Central Plateau Conservation Area that is in the WHA (fig. 1).

In common with the fire history study of southwest Tasmania, this paper aims to describe fires since the early 1800 s. The outcomes of this work are descriptions of the major fire events before the 1930s, maps of all known fires from the 1930s to the 1990s, and estimates of the area of different vegetation types burnt. For additional information on this project see Johnson \& Marsden-Smedley (2001).

\section{METHODS}

Aims

Using published papers, field work, aerial photographs and pre-existing fire history maps, this paper aims to build up a picture of the region's fire history before 2000. With the exception of the Walls of Jerusalem National Park and Central Plateau Conservation Area west of Great Lake (fig. 1), fires before 1930 have been described, with fires after 1930 being mapped. On the Central Plateau, fires before 1960-61 have been described and fires after this time have been mapped. The map of the 1960-61 fires and some later fires was obtained from Corbett (1995). Information on fires that occurred in the 1980s and 1990s was obtained from the Fire Management Section of the Parks and Wildlife Service.

Information from published papers, aerial photographs and field surveys was used to generate fire-history maps at 1: 25000 scale for the northern part of the WHA. Estimates of the area of different vegetation types burnt at different times have been made by laying the fire-history maps over the fire-attributes vegetation map published in the WHA Tactical Fire Management Plan (PWS 2000). 


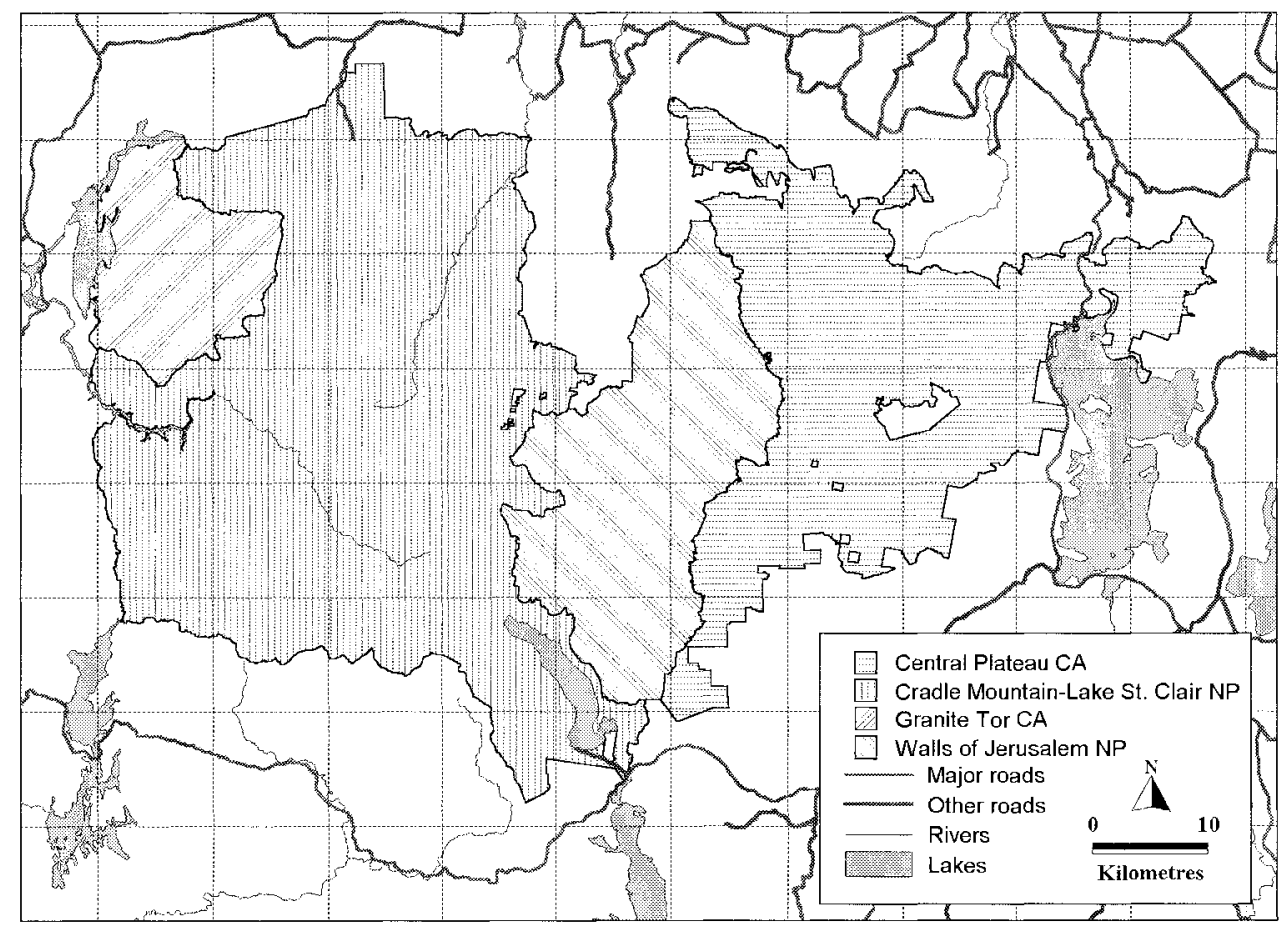

FIG. 1 - Ared examined in this project.

\section{Published Papers}

The following sources provided particularly useful information on historical fires: Tasmanian House of Assembly Journal, Legislative Council Journal, The Mercury, The Tasmanian Mail, The Weekly Courier, Explorers of Western Tasmania (Binks 1980) and $A$ View to Cradle (Haygarth 1998).

Although these references give an indication of where and when fires occurred, they generally contain minimal information on the size, extent and severity of the fire. While providing an overview of fires, they tend to concentrate on official expeditions, often undertaken by government employees, and to ignore exploration and burning by private parties. As a result, these sources almost certainly greatly underestimate the occurrence of fire in the study area. They have been used as spot references in the recording of fires from the 1820 s to 1930 .

\section{Aerial Photograph Interpretation}

Aerial photographs (held at the Department of Primary Industries, Water and Environment) taken of the project area between 1947 and 1982 were examined for fire boundaries. Corbett (1995) produced a map of fire boundaries for the Central Plateau WHA, spanning the period 1961 to 1993 . As a result, only photographs predating 1961 were examined for the present study.

The interpretation of fire boundaries on aerial photographs was made challenging by the highly variable quality and scale of the photographs. In particular, there were large differences in contrast between different aerial photograph projects, between runs within projects and even between adjacent photographs.

Long time intervals between photograph runs also created problems in interpretating fire scars; for example, no aerial photographs of the study area taken in the 1960 s were located. As a result, there are gaps of 20 to 26 years between aerial photograph runs over the whole project area. This complicated the interpretation of photographs from the 1970 s in particular, as fire scars could disappear (regenerate) or be hidden by subsequent fire events during this long interval. There is also an absence of early photographs pre-dating mapping done by Corbett (1995) covering the Central Plateau. Almost half of the Central Plateau Conservation Area assessed in this study had little or no coverage from before the late 1960 s to the mid1970 s.

Growth rates of different vegetation types after fire also created difficulties for mapping. Shrubby alpine vegetation holds fire scars for much longer than grassy or buttongrass moorland vegetation, which made the placement of fire boundaries across different vegetation types difficult. The mapping of frequently burnt areas and patchy fires (particularly in country with a large amount of rock scree, such as the Central Plateau) was found to be a much more difficult task than mapping large or high intensity fire events. Much of the area where patchy burning has traditionally taken place coincides with the areas described above as having insufficient aerial photograph coverage for mapping purposes (i.e., Central Plateau).

\section{Field Data}

Vegetation ages were collected from 57 sites within the study area. Primarily, ages were estimated from tea-tree and paper-bark ring counts (Leptospermum nitidum, L. lanigerum, L. scoparium, L. rupestre and Melaleuca squamea). With the exception of $L$. rupestre, these species have been widely used in studies of site age because of their reliable annual rings and widespread distributions (Jarman et al. 1988a, b, MarsdenSmedley 1998a, b, Marsden-Smedley et al. 1999). 
A dissecting microscope was used to make ring counts from the lower surface of cross-sections. Cross-sections were cut from as close to ground level as practical, dried and polished with up to 1200 grade sandpaper (MarsdenSmedley et al. 1999). The number of stems sampled at any one site ranged from two to 11 . Time and practicality constraints of remote area field trips (up to 10 days' duration) resulted in a small number of samples from some sites.

Node counts from Banksia marginata were used to assist in determining site age (Bell 1983, Jarman et al. 1988a, Marsden-Smedley et al. 1999). Nodes tended to be obscure and difficult to count on older banksias. As a result, banksias were used to gain an indication of minimum site age and, where possible, were used in conjunction with ring counts. Site ages were also obtained for 16 sites from Jarman $e t$ al. (1988a).

\section{RESULTS}

The results are divided into two time periods: before the 1930 s, and from the 1930 s to the 1990 s. The first of these periods relies on historical literature, while the second incorporates mapping from this project and contemporary literature.

\section{Fires before the 1930s}

On the night of the $24^{\text {th }}$ December, 1840, a fearful storm of lightning occurred here. It was for a long time unaccompanied by either rain or thunder; and the flashes, which succeeded each other at very short intervals, were singularly vivid; showing plainly at each recurrence, the migged outline of the wild landscape around us. As we were watching the storm from our rocky fortress, we witnessed a most unusual occurrence. The recent hot weather had parched the herbage of the plain to perfect dryness, and a flash, more tremendous than any that had preceded, suddenly set it in a blaze. We were beginning to be a little alarmed for the security of our position in the tenement we occupied, which was surrounded by dry herbage, mixed largely with dry brushwood, but shortly afterwards relieved from our apprehensions by a copious shower of rain extinguishing the fire. (J. E. Calder in 1840 at Christmas Rock on Lightning Plain, which is south of the study area (Calder 1849)).

The fire was now raging with fearful violence, the whole sky being blue with smoke, which made everything lurid and unnatural ... The country was black for miles; not a speck of green could be seen, except the myrtle forest which clothed the side of Mount Gell. (W. A. Tully near the upper Franklin River in 1859 . The fire was started by a spark from his camp fire.)

The occurrence of natural and accidental fires, such as those witnessed by Calder and Tully, cannot begin to compare with the widespread and deliberate use of fire during the latter part of the nineteenth century. Explorers and prospectors used fire as a tool to cut tracks into unmapped territory and to expose the substrate. The west coast mineral boom of the $1880 \mathrm{~s}$ created a demand for access to the mining areas of Zeehan and Mount Lyell and also for tracks to take prospectors and geologists into new regions.
Near Mount Kate, in the north of the study area, Fossey's (1827) expedition observed open country (Cradle Valley and Hounslow Heath) with stands of snow gums, pencil pines and fagus (Binks 1980). Gould's 1859 to 1860 expedition also noted relatively clear spurs and open country between Barn Bluff and Lake Windermere and noted that open moors existed south of Lake Will (Binks 1980). It is likely that fairly regular burning occurred over at least some of the buttongrass plains within the study area. Legge (1887) describes the Vale of the Cuvier as 'park-like' and studded here and there with clumps of young gums... We found it much overgrown, as it has not been burnt out for four or five years, and the walking was consequently very beavy ... On our return [from Lake Hermione] we found the buttongrass in the valley, and though it was drizzling at the time a buge fire sprung up at night and burnt all the following day, so that the next pedestrians who ascend Olympus will have better walking than we had.

In November 1896, large bushfires were observed by Innes (1897) while cutring and marking a track from Mole Creek to Rosebery (see quote at the beginning of this paper). In the tradition of the times, Innes' party fired the countryside to assist in their movement through it ... Aylett and Innes carried out their instructions well. Leaving my camp upon Granite Tor on February 2, they pushed through to Mount Black, firing the country anywhere there was a chance to burn it.

Marsden-Smedley (1998a) suggests that a large proportion of southwest Tasmania burned during the $1890 \mathrm{~s}$. This included much of the country between the West Coast Range, Hartz Mountains and the Southern Ranges. Further north, the latter part of the nineteenth century was also a time of fire.

The bushfires of 1897-98 started in December 1897; the last day of 1897 came to be called 'Black Friday'. These fires burned for most of the rest of that summer, devastating large areas. A column in the Illustrated Tasmanian Mail ( 8 January 1898) summed up the fires on the west coast (reported from Zeehan and all around, including the Northeast Dundas tramway, Mount Read, Mount Hamilton, Queenstown and Mount Lyell) under the heading 'Unprecedentedly extensive and disastrous fires'. It went on:

Very heavy bush fires have been raging with even increased vigour in this district for several days past, and more serious damage is reported at Zeehan and all around... The recent devastating bush fires on the West Coast have not been utterly devoid of redeeming points. They have cleared away miles of almost impenetrable bush and scrub, so that the prospector may now carry out his work with a tithe of the toil and trouble previously inseparable from bunting out lodes.

The Illustrated Tasmanian Mail (8 January 1898) reported that fires were also lit around Lake St Clair on either 26 or 27 December 1897. Photographs in the Archives Office of Tasmania show the extent of these fires. Photographs from 1901 show that fire had already taken its toll on the area around Mount Pelion West and Pinestone Valley (aged in this project to the mid- to late 1890s). However, this landscape was no stranger to fire. Dead trees are prevalent around Lake St Clair and Mount Arrowsmith in photographs from 1863 (Morton Allport collection 'First Views). The effects of fires near Mt Arrowsmith were also described by Walker (1887). Site ageing around Cradle Valley suggests that a major fire event occurred in the late 1890 s (probably $1897-98$ ). 
While surveying and cutting a track from Lake Selina to Lake St Clair in 1900, Ewart was forced to avoid the Coal Hill area (head of Cuvier Valley) becaue of fire (Ewart 1901):

On starting from Eldon Bluff to reach Lake St. Clair, everything proceeded satisfactorily until Pine Hill [Junction Hill] was surmounted, about seven miles out, when I noticed there was a dense smoke in the vicinity of Coal Hill, which lay in the direction I wished to take. Thinking bush fires were raging, I decided to make for the overland route from Hobart, taking a course south from Gould's Pyramid.

Kirkpatrick \& Balmer (1991) suggested that three major fires occurred in the late 1800 s and/or early 1900 s in the area around Cradle Mountain and Pencil Pine. Photographs from the 1920s show the area between Barn Bluff and Cradle Mountain and the slopes of Hansons Peak as burnt, while ageing of banksias indicates fires probably occurred near Lake Dove in the 1890 s and Lake Rodway in both the $1890 \mathrm{~s}$ and $1930 \mathrm{~s}$. There are signs of much older fires in the landscape, including one that may have burnt from the northwest over Hounslow Heath (Kirkpatrick \& Balmer 1991). The lowland grasslands and sedgelands around Cradle and Pencil Pine have been frequently burnt since European occupation (Kirkpatrick \& Balmer 1991).

Jetson (1993) stated that by the mid-1820s wild cattle had moved to the Central Plateau, by the 1830 s the seasonal movement of stock from lower to higher altitudes was common practice, and by the 1850 s firing of grasslands and buttongrass plains had become established practice. On the Central Plateau, it is difficult to separate the effects of fire and domestic grazing. However, according to Cullen (1995) the Central Plateau has suffered serious sheet erosion and degradation as a result of 150 to 170 years of grazing and burning (see also Banks 1972).

In the 1800 s and early 1900 s in western Tasmania the extensive use of fire in exploration and prospecting was a widely accepted and generally socially acceptable practice. Regardless of this, the use of fire was such that it led Counsel (1898) to make the following comments:

In new and expanding agricultural settlements there is a considerable demolition of timber beyond that which is actually necessary in the clearing of land, by reason of the extra prevalence of spreading fires; but one of the main points to which I desire to direct especial attention in this Report is the enormous consumption of valuable timber which is in the process of being destroyed in the Mining Districts, particularly on the West Coast... there is the wholesale and reckless destruction of the forest growth, young and old, by bush fires in all directions during many months of the year, whilst there is no constituted authority at the present time to prevent the lighting of such fires on the unoccupied Crown Lands, except where it has been specially reserved.

Perrin (1898) also made comments relating to the condition of Tasmanian forests stating that it:

... is infinitely worse to-day than it was at date of my Report in 1886-7. Another decade of waste, of private monopoly, of fierce bush fires, of neglect by the Government to check the damage to public property, must ultimately result in disaster to the industries and thousands of people dependent upon the timber resources of the Colony... The bush fires about Lyell, Zeehan, the Pieman, and Lake Dora, drc. have already destroyed timber which it will cost shareholders in the mines many thousands of pounds more than they would otherwise have had to pay to replace by drawing from other localities.

Perrin goes as far as to suggest that a stringent Fire Act be drafted without delay to prevent what he saw as the excessive and haphazard use of fire:

In order to clear prospecting claims it is quite an ordinary custom for the prospector to set fire to the timber and let the flames spread at will over as much of the surrounding countryside as they can reach ... This is ignorantly regarded as a creditable and serviceable exploit in 'clearing the country,' no consideration being given to the fact that timber destroyed in this haphazard fashion will be wanted later on, and can only be replaced at great cost ... But in addition to the miner, the careless use of fire by the splitters and wood-cutters must also be dealt with, and a comprehensive measure should therefore be framed at once to prevent the recurrence of those disastrous fires which have already wrought such havoc.

From the 1820 s to the 1920 s the use of fire in the study area was widespread and deliberate. As will be seen below, this pattern continued for the next few decades.

\section{Fires from the 1930 s to 1990 s}

The early 1930s was a time of extensive fires in southwestern and western Tasmania. According to MarsdenSmedley (1998a) the extent of fire in the 1930s was second only to its extent in the 1890 s. This trend of extensive fires appears to have extended to the north to include the area covered by this study. During the 1930s, there were several major fires. Kirkpatrick (1984) suggests two severe fire events (probably in 1933-34): one that burnt most of Pyramid Mountain and another that burned Rocky Hill. Fires were also observed near the Eldons by Warren (1936): . bushfires down Jane River way, smoke near Lake Vera and fires buming fiercely in the West. Westward the sky black and flame coloured. Near the Eldons a huge column of smoke rises steadily up above the clouds, a long straight column, opening at the top like a gigantic mushroom.

The major fire observed near the Eldons may have left the large fire scar mapped in the vicinity of Walled Mountain and Macs Mountain (fig. 2). It extends north at least as far as James Creek, east to the DuCane Range, up the valley of the Narcissus River to Falling Mountain, and west to near the Bluff River. Photographs from 1936 in Haygarth (1998) show burnt forest surrounding DuCane Hut, although it is not clear how extensive this fire was. Part of Mount Oakleigh was mapped as burnt on the 1947 aerial photographs and the adjacent February Plains show a history of fire from this time right through to the 1980s. The Cuvier Valley also has a history of fire, as seen on the aerial photographs and by stands of dead pencil pines (Johnson \& Marsden-Smedley 2001).

Further east on the Central Plateau, fire events observed on the 1947 aerial photographs were difficult to map. Although there is a distinct fire boundary in the vicinity of Chapter Lake, Lake Bill, Lake Louisa, Lake Adelaide and to the west and north of Lake Myrtle, a complete boundary could not be given to this fire. As a result it is not shown in figure 2. Another boundary, potentially from much the same time, was located in the area between Lake St Clair and Travellers Rest Lake, with evidence of fire extending in a patchy nature to the east. An important detail recorded by Jetson (1993) in a personal interview with shepherd Jacky Reid states that the 1933-34 fires extended to Lake Naomi and Gowanbrae.

Another major fire event occurred between 1947 and 1953 (most probably in the early 1950s) in the vicinity of 

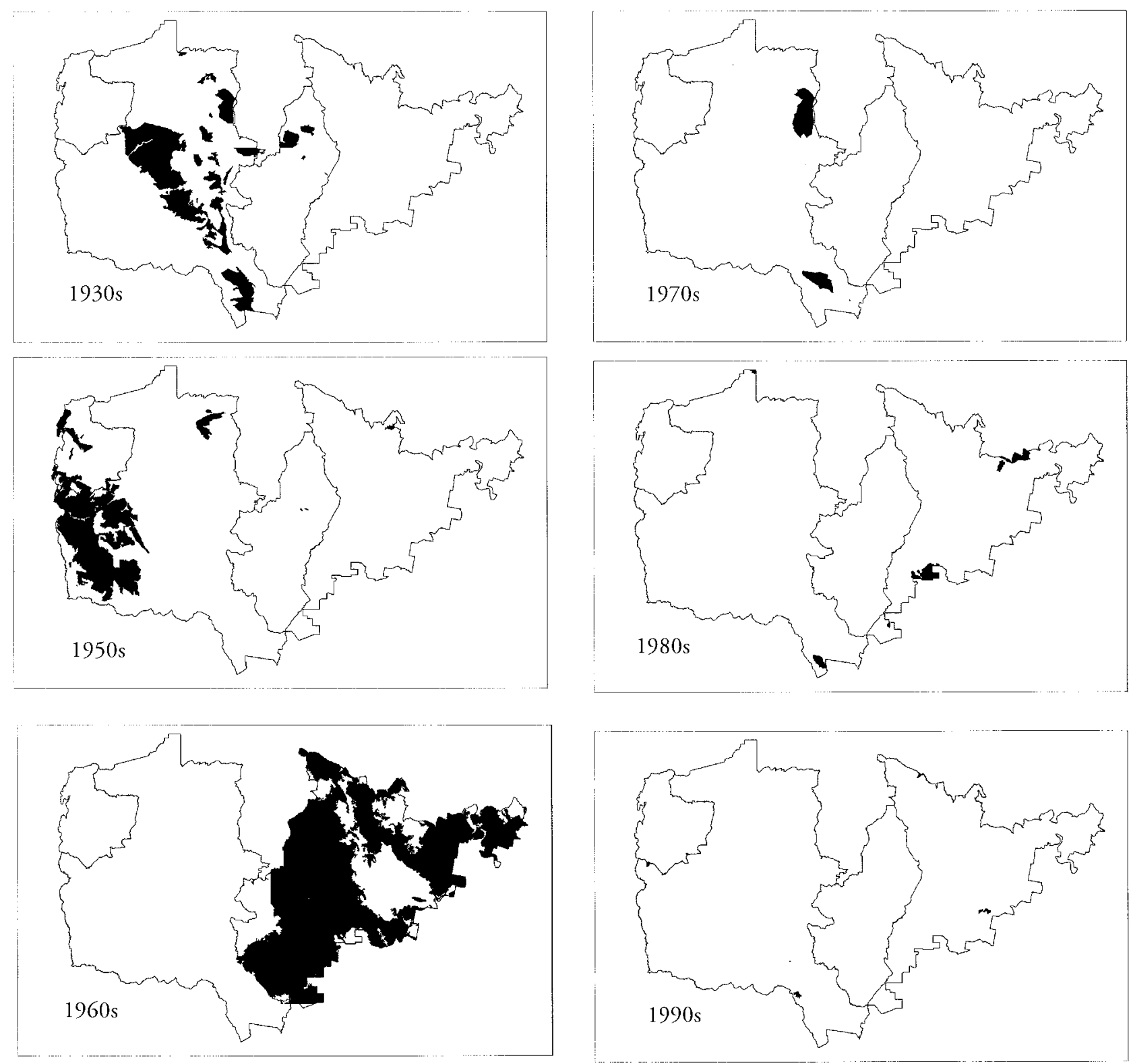

FIG. 2 - Approximate areas burnt in different decades. Due to the limitations of this study, the areas burnt are likely to be underestimated. No fires were recorded from the 1940s; see figure 1 for a more detailed map of the study area.

Eldon Range, Lake Ewart, Murchison River and the area now covered by Lake Mackintosh. Kirkpatrick \& Whinam (1988) suggest (from banksia node counts) that there is evidence over most of the Lake Ewart and Dome Hill area of at least one fire event in the 1950 s. They also suggest that some coniferous heath on both Eldon Bluff and Dome Hill indicates that parts of these areas have not been burnt for a considerable number of years. One of the fire boundaries mapped in the present study suggests that the southern, lower slopes of Dome Hill burnt between 1947 and 1953 but that the upper slopes to the north did not.

Corbett (1995) mapped the boundary of the 1960-61 fire where it occurred in the part of the Central Plateau Conservation Area that is in the WHA. Additional areas were mapped as burnt near Lake Laura, on the Traveller Range and adjacent to Lake St Clair by the present study. They may also have burnt in 1960-61.
There is strong evidence from both anecdotal and government records that the 1960-61 fires were deliberately lit by highland graziers in order to clean out thick vegetation and promote green-pick for sheep and cattle grazing. However, it is worth noting that most of the area within which the 1960-61 fires were lit was outside the areas that were approved for grazing at that time (V. Dell pers. comm.).

Until the 1960s, grasslands and sedgelands in Cradle Valley were burned at relatively frequent intervals (Kirkpatrick \& Balmer 1991). However, site ageing from around Cradle Valley suggests that these fires were restricted to the valley floor and did not burn the surrounding slopes. The plains near Lake Caruthers also appear to have been patchily burnt just before 1953 . These fires must have been quite localised, as site ageing slightly north of Mount Campbell indicates that area is long unburnt. Parts of the 
Central Plateau also continued to be frequently burnt at this time. Jetson (1993) notes that, although these fires were meant to be low blazes that did not damage root systems, sometimes misjudgments were made that transformed them into raging infernos.

Fires occurred in the Cuvier Valley and part of the southern and western slopes of Mount Olympus in 1976. With the exception of this fire and the 1960-61 Central Plateau fire, no major fires were mapped post-1953.

\section{Areas Burnt in Different Fires}

The fires mapped in this study burnt in excess of 129000 ha (table 1, fig. 2). The areas burnt in these fires has been laid over a vegetation map developed as part of the World Heritage Area Tactical Fire Management Plan (PWS 2000). This vegetation map was derived from the World Heritage Area vegetation mapping project (Corbett unpubl.) and the Resource Assessment Commission vegetation map (Kirkpatrick \& Brown 1991).

\section{DISCUSSION}

Over the past century, the fire history of the northern part of the WHA has been one of periods of few fires followed by a large fire. The major impacts on fire-sensitive vegetation mostly occurred during these large fires. This finding parallels the fire history of the southern part of the WHA (MarsdenSmedley 1998a), and has been reported to be the situation in other regions of the world (Luke \& McArthur 1978, Christensen et al. 1989, Romme \& Despain 1989).

Another major change in the region's fire history concerns the locations where fires occurred. Before the 1970s, fires occurred throughout the study area, while from the $1970 \mathrm{~s}$ on, fires mostly occurred on the region's margins and major access routes (fig. 2).

During periods of few fires, it appears that in fire-adapted and fire-dependent vegetation the ratio of dead to live fuel, fuel continuity and total fuel load all increase. This results in fires burning over a wider range of conditions, with faster rates of spread and higher intensities than would otherwise be the case (Marsden-Smedley 1998b, MarsdenSmedley et al. 1999). This is particularly the situation in old-growth buttongrass moorlands (where site age exceeds about 35 years), which can act as a wick to carry fire rapidly through the landscape threatening other vegetation types, including fire-sensitive types (Marsden-Smedley $\& x$ Kirkpatrick 2000).

One of the major questions arising from fire-history studies relates to interactions between the probability of fires starting, the characteristics of the vegetation's fuels when fires occur, and the likelihood that these fires will threaten fire-sensitive vegetation types. In regard to the probability of fires starting, it is highly likely that in the area covered by this study there has been a major reduction in the number and extent of unauthorised ignitions over the past 30 to 40 years. This reduction may be the result of a decline in the social acceptability of unauthorised burning-off of the bush. However, as the fuels age in the region's fire-promoting buttongrass moorlands and also in wet scrub and wet eucalypt forests, it is highly probable that they will carry fire over a wider and wider range of conditions. These increases in flammability may result in significant areas of fire-sensitive vegetation being burnt in the future. At present, we do not have sufficient information to comprehensively address these issues. However, it would be prudent to ensure that they are examined and that any new information is incorporated into the management practices for the region.

\section{AUTHORS' NOTE}

This paper is not a definitive study of fire in the northern part of the World Heritage Area of Tasmania. Only obvious fire scars have been mapped from the acrial photographs. The vegetation type and likely flammability of these areas has generally not been identified, which probably has resulted in the extent of fire being underestimated. This paper should therefore be viewed as a overview of fire in this area and be

TABLE 1

Area burnt and total area of different vegetation types

\begin{tabular}{|c|c|c|c|c|c|c|c|c|c|c|c|c|}
\hline Decade & As & $\%$ & Rs & $\%$ & Bs, Ws & $\%$ & Wf & $\%$ & $\mathrm{Rf}$ & $\%$ & Total & $\%$ \\
\hline $1930 \mathrm{~s}$ & 7436 & 5.0 & 6072 & 32.9 & 5349 & 23.0 & 776 & 2.1 & 2677 & 3.5 & 22310 & 7.1 \\
\hline $1940 \mathrm{~s}$ & 0 & 0.0 & 0 & 0.0 & 0 & 0.0 & 0 & 0.0 & 0 & 0.0 & 0 & 0.0 \\
\hline $1950 \mathrm{~s}$ & 2975 & 2.0 & 1717 & 9.3 & 3678 & 15.8 & 2379 & 6.4 & 2935 & 3.8 & 13684 & 4.4 \\
\hline $1960 \mathrm{~s}$ & 69028 & 46.1 & 1441 & 7.8 & 324 & 1.4 & 12829 & 34.7 & 946 & 1.2 & 84568 & 27.1 \\
\hline $1970 \mathrm{~s}$ & 1084 & 0.7 & 58 & 0.3 & 189 & 0.8 & 1064 & 2.9 & 927 & 1.2 & 3322 & 1.1 \\
\hline $1980 \mathrm{~s}$ & 3462 & 2.3 & 157 & 0.9 & 8 & 0.0 & 1151 & 3.1 & 78 & 0.1 & 4855 & 1.6 \\
\hline $1990 \mathrm{~s}$ & 219 & 0.1 & 0 & 0.0 & 55 & 0.2 & 0 & 0.0 & 0 & 0.0 & 274 & 0.1 \\
\hline Total burnt & 84204 & 56.2 & 9445 & 51.3 & 9602 & 41.2 & 18198 & 49.2 & 7563 & 9.9 & 129013 & 41.3 \\
\hline Total area & 149744 & 48.0 & 18429 & 5.9 & 23286 & 7.5 & 37019 & 11.9 & 76613 & 24.5 & 312263 & - \\
\hline
\end{tabular}

As = alpine and subalpine heath; Rs = subalpine rainforest; $\mathrm{B} s=$ buttongrass moorland; Ws = wet scrub; $\mathrm{He}=$ wet eucalypt foresr; $\mathrm{Rf}=$ rainforest; total burnt = total area burnt in the fires mapped in this study; total area = the total area covered by this study; The figures on areas burnt in these fires should be taken as approximate areas only and used in conjunction with the fire descriptions. 
used as a structure for subsequent information on fire history.

\section{ACKNOWLEDGEMENTS}

Many people assisted with this project, without whose help it could not have been completed. In particular, we thank the project's field assistants - Vicky Bonwick and Martin Jack. Sib Corbett, Chris Corbett and John Corbett provided useful information for performing field work in the Eldon Range. Sib Corbett provided the map of the 1960-61 fires, greatly assisting the mapping for our study, while Roger Ling transformed the raw fire history maps into digitised format and produced the final maps. The Parks and Wildlife staff at Cradle Mountain and Lake St Clair, in particular Kent McConnell, provided assistance with field work. The staff of Service Tasmania provided essential assistance with the aerial photographs, while the staff of the Archives Office of Tasmania provided assistance with historical sources.

\section{REFERENCES}

BAnKs, M.R., (Ed.), 1972: The Lake Country of Tasmania. Symposium conducted by the Royal Society of Tasmania, Poatina, Tasmania, 11-12 November 1972. 199 pp.

BeLl, A., 1983: Fire and rainforest in Tasmania. Ecos 37: 3-8,

Binks, C.J., 1980: Explorers of Western Tasmania. Mary Fisher Bookshop, Launceston. 262 pp.

Brown, M.J., 1988: Distribution and Conservation of King Billy pine. Forestry Commission, Hobart.

Calder, J.E., 1849: Some account of the country lying between Lake St Clair and Macquarie Harbour. Tasmanian Journal of Natural Science, Agriculture, Statistics, \& 3: 415-429.

Christensen, N.L., Agee, J.K., Brussard, P.F., Hughes, J., Knight, D.H., Minshall, G.W., Peek, J.M., Pyne, S.J., Swanson, F.J., Thomas, J.W., Wells, S., Williams, S.E. \& WRIGHT, H.A., 1989: Interpreting the Yellowstone fires of 1988. BioScience 39: 678-685.

Conbe'1", S., 1995: Vegetation of the Central Platedu, Tasmanian Wilderness World Heritage Area. Wildlife Report 95/3. Nature Conservation Branch, Department of Primary Industries, Water and Environment, Hobart.

Counsel, E.A., 1898: Timber industry in Tasmania. Parliament of Tasmania Journal: report 48. Parliamenr of Tasmania, Hobart.

Cullen, P., 1995: Land degradation on the Central Plateau, Tasmania. Occasional Paper 34. Parks and Wildlife Service, Tasmania.

Ewart, R., 1901: Lake Selina to Lake St Clair. House of Assembly Journal: report 47. Parliament of Tasmania, Hobart, Tasmania.

Fossey, J., 1827: Sketch of the history of Van Diemen's Land. Quoted in Binks (1980).

GovLd, C., 1860: House of Assembly Journal: report 4. Parliament of Tasmania, Hobart.

Haygarth, N., 1998: A View to Cradle; a History of Tasmania's Forth River High Country. Published by the author, Canberra: 213 pp.

InNES, E.G., 1897: Route to the west coast: Report of Mr. Surveyor Innes upon the track from Mole Creek to Rosebery, Mt Reid. Parliament of Tasmania Journal, report 43. Parliament of 'Tasmania, Hobart.

Jarman, S. J., Kantvilas, G. \& Brown, M.J., 1988a: A Preliminary Study of Stem Ages in Buttongrass Moorlands. Research Report 3, Tasmanian Forest Research Council, Hobart.
Jarman, S.J., Kantvilas, G. \& Brown, M.J., 1988b: Buttongrass Moorland in Tasmania. Research Report 2, Tasmanian Forest Research Council, Hobart.

Jetson, T., 1993: A history of fire in the Bronte region. Papers and Proceedings of the Tasmanian Historical Research Association 40: 170-182.

Johnson, K.J. \& Marsden-Smedley, J.B., 2001: Fire History of the Northern Part of the Tasmanian Wilderness World Heritage Area. Fire management Section, Parks and Wildlife Service, Department of Primary Industries, Water and Environment, Hobart.

KirKPatricK, J.B., 1984: Tasmanian high mountain vegetation II. Rocky Hill and Pyramid Mountain. Papers and Proceedings of the Royal Society of Tasmania 118: 5-20.

KirkPATRiCK, J.B. \& BaLMER, J.M., 1991: The vegetation and higher plant flora of the Cradle Mountain-Pencil Pine area, Northern Tasmania. In M.R. Banks, S.J. Smith, A.E. Orchard and G. Kantvilas (Eds): Aspects of Tasmanian Botany; a Tribute to Winifred Curtis. Royal Society of Tasmania, Hobart: 119-148.

KirkPATrick, J.B. \& BRown, M.J., 1991: Reservation Analysis of Tasmanian Forests. Resource Assessment Commission Forest and Timber Inquiry Consultancy Series No. FTC91/16.

KirKPATRICK, J.B. \& Whinam, J.P., 1988: Tasmanian high mountain vegetation III. Lake Ewart, Dome Hill and Eldon Bluff. Papers and Proceedings of the Royal Society of Tasmania 122: 145-164.

LEGge, W.V., 1887: The highlands of Lake St. Clair. Papers and Proceedings of the Royal Society of Tasmania.

LuKE, R.H. \& MCARThur, A.G., 1978: Bushfires in Australia. CSIRO Division of Forest Research, Department of Primary 1ndustry, Canberra.

Marsden-Smedley, J.B., 1998a: Changes in the fire regime of southwest Tasmania over the last 200 years. Papers and Proceedings of the Royal Society of Tasmania 132: 15-29.

Marsden-Smedley, J.B., 1998b: Fire and fuel in Tasmanian buttongrass moorlands. Unpubl. PhD thesis, School of Geography and Environmental Studies, University of Tasmania, Hobart. 191 pp.

Marsden-Smedley, J.B. \& Kirkpatrick, J.B., 2000: Fire management in Tasmania's Wilderness World Heritage Area: ecosystem restoration using Indigenous-style fire regimes? Ecological Management and Restoration 1: $195-$ 203.

Marsden-Smedley, J.B., Rudman, T., Catchrole, W.R. \& Pyrke, A., 1999: Buttongrass moorland fire behaviour prediction and management. TasForests 11: 87-107.

PERRIN, G.S., 1898: Forests of Tasmania: their conservation and future management. Parliament of Tasmania Journal, report 48. Parliament of Tasmania, Hobart.

Peterson, M., 1990: Distribution and Conservation of Huon Pine. Forestry Commission, Hobart.

PWS, 1999. Tasmanian Wilderness World Heritage Area Management Plan. Parks and Wildlife Service, Department of Primary Industries, Water and Environment, Hobart.

PWS, 2000: World Heritage Area Tactical Fire Management Plan. Unpubl. report by the Fire Management Section, Parks and Wildlife Service, Department of Primary Industries, Water and Environment, Hobart.

Robertson, D.I. \& Duncan, F., 1991: Distribution and Conservation of Deciduous Beech. Forestry Commission Tasmania and Department of Parks, Wildlife and Heritage, Hobart.

Romme, W.H. \& DespaIN, D.G., 1989: Historical perspective on the Yellowstone fires of 1988; a reconstruction of prehistoric fire history reveals that comparable fires occurred in the early 1700s. BioScience 39: 695-699.

Tuluy, W. A., 1859: The western country. Mercury Newspaper. 26 April 1859. 
WALKER, J. B., 1887: Walk to the West. Royal Society of Tasmania, Hobart. 76 pp.

WARREN, R., 1936: Diary of two wretched females on a trip to Frenchman's Cap. The Tasmanian Tramp 5: 44-48. Hobart Walking Club, Hobart.

(accepted 9 December 2002) 